Article

\title{
Evaluation of LEED for Neighbourhood Development and Envision Rating Frameworks for Their Implementation in Poorer Countries
}

\author{
Jose Manuel Diaz-Sarachaga, Daniel Jato-Espino * (1) and Daniel Castro-Fresno \\ GITECO Research Group, Universidad de Cantabria, Avd. de los Castros 44, 39005 Santander, Spain; \\ dsarachagajm@unican.es (J.M.D.-S.); castrod@unican.es (D.C.-F.) \\ * Correspondence: jatod@unican.es; Tel.: +34-942-203-943
}

Received: 12 January 2018; Accepted: 12 February 2018; Published: 12 February 2018

\begin{abstract}
The unstoppable world population growth is increasing the concentration of people in urban settlements and the number of megacities, especially in developing countries where urbanization exacerbates social and economic inequalities. Green rating systems have been launched during the last decades to facilitate the assessment of sustainable development in terms of building and infrastructure, including the evaluation of sustainable urban development through the study of communities. This article assesses two of the most renowned sustainable rating systems through the prism of economy, environment and society and the international actions undertaken toward the promotion of sustainable development worldwide, in order to determine their effectiveness to assess urban development in poorer nations. Hence, Leadership in Energy and Environmental Design for Neighbourhood Development (LEED ND) and Envision, both from the United States, were chosen as representatives of building and infrastructure fields, respectively, so that the Sustainable Development Goals (SDGs) and the New Urban Agenda (Habitat III) were the benchmarks selected to define the sustainability aspects required to evaluate their potential application in less developed countries. The absence of metrics in the New Urban Agenda led to relate its commitments to the SDGs, which revealed that the prerequisites and credits included in LEED ND and Envision mainly focused on managerial and environmental aspects and disregarded the economic and social dimensions. Consequently, the premises under which LEED ND and Envision were developed must be updated and complemented with the two latest guidelines recently adopted by the United Nations in the field of urban and sustainable development.
\end{abstract}

Keywords: Envision; Habitat III; LEED ND; sustainable rating system; sustainable urban development; SDGs

\section{Introduction}

The definition of sustainable development was reformulated by the European Commission (EC) in 2001 through the consideration of the holistic concept of the Triple Bottom Line (TBL) as the economic growth that encourages the progress of society while respecting the environment [1]. Although the balance of these three pillars contributes to achieving sustainability goals, the existence of multiple interrelationships among them highly complicates this purpose. Furthermore, management should complement the three aspects of sustainability as a new dimension that enables meeting sustainability goals by implementing a series of standards and frameworks.

High population density and its outstanding impacts on society and economy make urban development relevant in terms of sustainability. Urban areas concentrate most locations of major consumption of resources, production of waste and pollution, degradation of environmental conditions, social conflicts and needs of infrastructure. The studies prepared by the United Nations (UN) 
predict a future world population of 8.5, 9.7 and 11.2 billion inhabitants in 2030, 2050 and 2100, respectively [2]. Urban settlements are inhabited by more than $50 \%$ of global population at present, a rate which is projected to reach $60 \%$ by 2030 . The least developed countries of Asia, Africa and Latin America, where sustainable development is not being adequately addressed, host about $70 \%$ of this population [3]. Some predictions reveal an expected increase of 2.5 billion people in urban areas by 2050 as a consequence of global population growth and urbanization, with $90 \%$ of this increment located in Asia and Africa [4], where sustainable development is lower. Moreover, megacities with 10 million people or more should be also considered in the analysis of urban development. The ten megacities with 153 million people (7\% of world urban dwellers) registered in 1990 rose to twenty-eight with 453 million inhabitants in 2014 (12\% of world urban population). The geographic distribution of these megacities revealed that 16 of them were located in Asia, followed by both Latin America and Africa with four, Europe with three and North America with two. The world is projected to have 41 megacities by 2030, according to UN forecasts [4].

Metrics and evaluation of policies and programs, socio-economic aspects, amenities, resources, pollutants and any other processes that could influence cities, wealth and social welfare are required for the development of sustainable urban settlements. The use of suitable indicators and research practices, combined with the promotion of public participation, can enhance urban policies and facilitate the achievement of sustainability goals. Thus, the existence of measurable metrics is crucial for monitoring urban planning and management [5].

Several sustainable rating systems have been developed during the last decades to monitor and appraise the degree of sustainability of buildings and infrastructures. LEED for Neighbourhood Development (LEED ND) [6] and Envision [7] highlight for being two of the most suitable and complementary tools to assess sustainability in urban developments. Although the United States Green Building Council (USGBC) launched two new pilot certification programs in December 2016 such as LEED Cities and LEED Communities through the Arc Platform, the current version LEED ND $\mathrm{v} 4$ was considered in this study because its broader range of credits and prerequisites in comparison with LEED Cities and LEED Communities, as well as due to its successfully implementation in diverse international projects during the last years.

On the one hand, LEED ND combines guidelines of smart growth, planned urbanism and sustainable building with a set of national regulations for green design at the neighbourhood scale, which was the spatial resolution selected to analyse urban development in this research. In contrast with the complexity associated with the size of entire cities, the evaluation of neighbourhoods enables deploying measures to emphasize sustainable principles. Furthermore, LEED ND involves more concerns beyond environment than other systems, including social issues. On the other hand, the Envision system encourages sustainable infrastructure through graded credits belonging to social, economic, environmental and managerial dimensions which are applicable to all projects. In contrast to other tools, Envision rewards restorative initiatives intended to enhance sustainability during all the stages of a project. Its focus on major communities concerns, the integration of infrastructure into existing systems and the consideration of resilience indicators emphasize the contribution of this framework to developing the sustainable urban environment.

This research aimed at appraising the potential application of the LEED ND and Envision tools in developing countries, based on the consideration of relevant aspects for the assessment of sustainable urban development according to the Sustainable Development Goals (SDGs) and resolutions from the Habitat III Conference (New Urban Agenda), where social and economic perspectives were considered in the analysis of the transformation of countries due to urban development. Whilst green community score systems act as efficient tools to monitor the progress of urban areas towards sustainability, infrastructure frameworks promote the consideration of the TBL in projects which support the sustainable interconnectedness and development of towns and cities. Due to the location of most megacities in developing countries, where the SDGs are mainly oriented, the deployment of rating systems is highly recommended to guarantee the sustainable development of these countries 
in the future. The article correlated the items of the New Urban Agenda to the SDGs to verify their degree of concordance. Then, the social, economic, environmental and managerial dimensions were set as a benchmark to assess the coverage of the SDGs and the New Urban Agenda in terms of sustainable development.

\section{International Endeavours to Foster Sustainable Development}

The importance of having accurate indicators to support the decision-making processes related to sustainable development was reaffirmed in 1992 in The Rio Declaration on Environment and Development [8]. The Work Programme on Indicators of Sustainable Development [9] was entrusted by the Commission on Sustainable Development (CSD) [10] in 1995, with the purpose of providing the first two sets of CSD before 2001. As a consequence of the determinations adopted by the CSD and the World Summit on Sustainable Development in 2002 [11], the Millennium Development Goals (MDGs) [12] were launched as a new revised edition. The last set of CSD indicators were implemented in 2007 as the result of the correlation among the MDGs, the Agenda 21 [8] and the Johannesburg Plan of Implementation [13].

The Millennium Summit held in September 2000 [14] adopted the UN Millennium Declaration, including the 8 MDGs to be achieved by 2015. Major issues associated with extreme poverty, education, gender inequality and environmental sustainability were included in them. At the end of 2015, all MDGs were replaced by 17 new goals named Sustainable Development Goals (SDGs) [15]. Global and national indicators were also determined to monitor the achievement of goals and targets involved in the SDGs. Despite the large number of sustainable indicators, the concept of sustainability was explicitly undertaken by both the MDG \#7 ("Ensure Environmental Sustainability"), which aimed at integrating the tenets of sustainable development into national regulations and preserve natural resources, and the SDG \#11 ("Sustainable Cities and Communities"), which seeks to make cities inclusive, safe, resilient and sustainable.

Millions of urban inhabitants worldwide upgraded their living conditions since the UN Conferences on Human Settlements held in Vancouver in 1976 (Habitat I) [16] and in Istanbul in 1996 (Habitat II) [17], as well as due to the adoption of the MDGs and SDGs in 2000 and 2015, respectively. However, aspects like famine and poverty, gender inequalities, health, education and environmental impacts, among others, are still barriers to overcome to stimulate sustainable development worldwide, especially in urban settlements where population is highly concentrated. The Habitat III Conference held in Quito in 2016 [18] took the challenge of previous UN initiatives to readdress the urbanization issue by implementing actions focused on planning and design, funding, governance and sustainable development.

\subsection{Sustainable Development Goals (SDGs)}

The Rio+20 Conference held in 2012 [19] approved the 2030 Agenda for Sustainable Development, which included 17 objectives to address environmental, political and economic issues, known as Sustainable Development Goals (SDGs). Thus, this document combine actions in which people, planet and prosperity are all involved. The end of poverty, hunger, gender inequalities and the enhancement of human health are crucial for the sustainable welfare of people. Initiatives to mitigate impacts due to climate change, protect land and biodiversity from degradation and efficiently manage natural resources by implementing responsible consumption and production patterns should be launched for the planet. The prosperity of people should be promoted through peaceful, just and inclusive societies, decent work and economic growth. The joint engagement of public and private sectors all over the world is essential to achieve the goals set in the Agenda. Table 1 shows the list of current SDGs in comparison with the former MDGs they replaced. 
Table 1. Millennium Development Goals (MDGs) and Sustainable Development Goals (SDGs) lists.

\begin{tabular}{cccc}
\hline MDG \# & Concept & SDG \# & Concept \\
\hline 1 & Eradicate Extreme Poverty and Hunger & 1 & No Poverty \\
2 & Achieve Universal Primary Education & 2 & Zero Hunger \\
3 & Promote Gender Equality and Empower Women & 3 & Good Health and Well-being \\
4 & Reduce Child Mortality & 4 & Quality Education \\
5 & Improve Maternal Health & 5 & Gender Equality \\
6 & Combat HIV / AIDS, malaria and other diseases & 6 & Clean Water and Sanitation \\
7 & Ensure Environmental Sustainability & 7 & Affordable and Clean Energy \\
8 & Global Partnership for Development & 8 & Decent Work and Economic Growth \\
& & 9 & Industry, Innovation and Infrastructure \\
& & 10 & Reduced Inequalities \\
& & 11 & Sustainable Cities and Communities \\
& & 12 & Responsible Consumption and Production \\
& & 13 & Climate Action \\
& 14 & Life Below Water \\
& & 15 & Life on Land \\
& & 16 & Peace, Justice and Strong Institutions \\
\hline
\end{tabular}

From 2000 to 2015, more than 1 billion people left extreme poverty condition, whilst child mortality and primary school leaving decreased by more than half and HIV / AIDS infections were reduced by $40 \%$, thanks to the actions taken in the frame of the UN Millennium Declaration. The SDGs not only aim to fulfil the MDGs that were not fully achieved, but they also consider new concerns in the field of environment, resources management, governance and partnerships. However, the fully eradication of poverty and hunger worldwide remain like the main challenge to be met for promoting sustainable development worldwide.

As shown in Figure 1, the distribution of SDGs in the four dimensions that determine sustainable development (social, environmental, economic and managerial) is balanced, in contrast with the predominant orientation of the MDGs towards the social pillar. Hence, social and environmental aspects account for 5 SDGs, followed by the managerial and economic dimensions with 4 and 3 SDGs, respectively. Infrastructure and cities are mainly considered in SDGs \#9 and 11. The former reaffirms that investments in infrastructure are crucial to achieve sustainable development and empower communities in many countries, whilst the latter indicates a specific orientation towards the transformative opportunity to make cities and communities more sustainable.

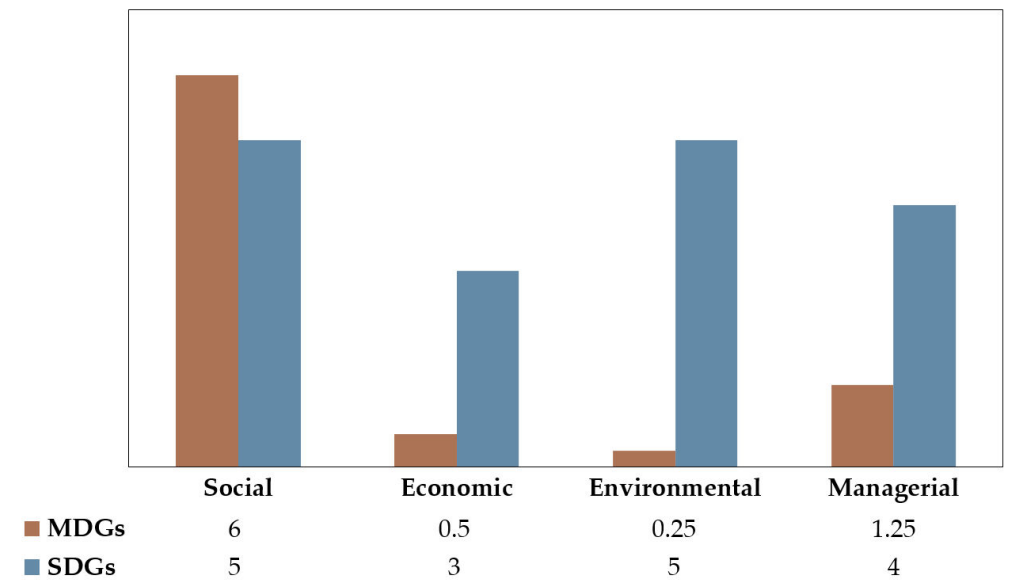

Figure 1. Distribution of the Millennium Development Goals (MDGs) and Sustainable Development Goals (SDGs) across the sustainable dimensions.

\subsection{Habitat III Conference: The New Urban Agenda}

At present, approximately $2 \%$ of the total land in the planet is occupied by cities, which are its main economic engine through the generation of $70 \%$ of Gross Domestic Product (GDP) worldwide. 
Moreover, over $60 \%$ of global energy consumption, $70 \%$ of Greenhouse Gas (GHG) emissions and 70\% of global waste are produced in urban settlements [3].

The trend of rising urban population growth confers urbanization a key role in the transformation of our planet over next decades. Cities concentrate most economic activities, social inequalities, cultural expressions and environmental impacts requiring specific actions in terms of infrastructure, housing, employment, health and education, among others.

The New Urban Agenda was adopted by most world leaders in the UN Habitat III Conference as a new global framework able to lead sustainable urban development by protecting environment, enhancing planning and management and promoting liveability in urban areas as drivers of wealth and social well-being. The Agenda was incorporated into the resolution 71/256 approved by the UN General Assembly on 23 December 2016, which reaffirmed the global commitment towards sustainable urban development as a trigger of sustainable development at global, regional, national and local levels, where all stakeholders are encouraged to participate. As stated in its item \#9, the establishment of the New Urban Agenda also endorses all principles of the 2030 Agenda in an integrated manner. Furthermore, it facilitates the achievement of the SDGs covering the objective $\# 11$, concerning the inclusiveness, safety, resilience and sustainability of urban settlements. The full compliance of the Agenda is a responsibility for national governments and local authorities, which should be supported by the international community through technical and financial partnership and assistance.

However, this document only considers general principles, recognitions and compromises, without any reference to quantitative metrics, targets or indicators. Key commitments included therein provide basic services for all citizens, avoiding discrimination, ensuring the accessibility of equal opportunities to women and disadvantaged people, enhancing social well-being, decreasing the impact of natural disasters by strengthening urban resilience, implementing measures to face climate change and pollution, promoting sustainable infrastructures and upholding fundamental rights of refugees and displaced people.

\section{Urban Sustainability Indicators and Rating Systems}

The assessment of the socio-economic and environmental effects of infrastructure, pollution, stakeholder participation, access to basic services and natural resources management is being undertaken through urban sustainability indicators, which enable the identification and solution of concerns via good governance practices.

The selection of indicators, including standardization and data availability, is crucial to address sustainable development by assessing and comparing them in similar urban areas, which also enables their validation and enhancement [20]. Furthermore, the efficient implementation of indicators relies on being locally-relevant, working at the city scale and addressing the sustainability needs of the location where they are being used [21].

Although standardization contributes to strengthening cooperation and sharing knowledge among stakeholders [22], data availability should also be considered when selecting indicators to monitor sustainability progress and achievement, because sometimes there is often little or no consideration of what data is available when indicators are proposed. The inexistence or lack of proper data can make the implementation of metrics useless.

A wide range of indicator tools have emerged in the last years., some of them exclusively focused on European cities such as The European Environmental Agency (EEA) Urban Metabolism Framework [23], The European Green Capital Award [24], The European Green City Index [25], The Reference Framework for Sustainable Cities [26], The Urban Ecosystem Europe [27] and The Urban Sustainability Indicator [28]. Some others, like the Global City Indicators Programme [29] and Indicators for Sustainability [30], are referred to a geographical context outside Europe [5].

Alongside LEED ND, other frameworks were developed during the last years, such as Building Research Establishment Environmental Assessment Method (BREEAM) Communities in the UK [31], 
Comprehensive Assessment System for Building Environmental Efficiency for Urban Development (CASBEE-UD) in Japan [32], Sustainability Tools for Assessing and Rating Communities (STAR) [33], The Eco ${ }^{2}$ Cities Initiative [34] and Green Star Communities [35].

Regarding sustainable infrastructure schemes, in the last two decades some institutions have also created comprehensive rating systems for evaluating sustainability across the design, construction and operation stages of infrastructures, such as Envision in the USA [7], Infrastructure Sustainable [36] rating tool in Australia and Civil Engineering Environmental Quality [37] in the UK.

\subsection{LEED for Neighbourhood Development (LEED ND)}

LEED is a certification system designed by the USGBC to foster sustainability practices in the building sector. The program covers different phases of the project lifecycle such as design, construction, operation and maintenance to achieve high levels of sustainability by implementing a series of guidelines and frameworks. Optimizing natural resources, promoting green energies, reducing environmental impacts and improving indoor condition for building occupants are some of the main goals sought by LEED, which comprises a series of mandatory prerequisites and voluntary credits that projects should meet. Four certification levels are determined according to the final score reached: Certified, Silver, Gold and Platinum.

The first pilot version of LEED ND was launched in 2007, whilst its present version, named LEED ND v4, was issued in 2014. The system can only be applied to neighbourhood developments with at least two habitable buildings and not exceeding 1500 acres. Three categories of credits are considered in the framework: smart location and linkage (SLL), neighbourhood pattern and design (NPD) and green infrastructure and buildings (GIB). Developing existing communities and public infrastructure systems using existing urban spaces and limiting urban footprint is the primary goal of SLL. NPD mainly focuses on walkable streets, access to public and green areas, promotion of compact and mixed-use developments that encourages walking and cycling. The implementation of efficient green practices in the design, construction and retrofit of buildings is involved in GIB. Innovation and design process (IDP) and regional priority credit (RPC) are also scored by LEED. IDP awards projects whose performance is higher than conventional, whilst RPC grants extra points to projects located in specific areas. Table 2 shows the list of prerequisites and credits included in LEED ND version 4.

\subsection{Envision Sustainable Infrastructure Rating System}

The Envision system is the result of the partnership between the Zofnass Program for Sustainable Infrastructure at Harvard University and the Institute for Sustainable Infrastructure (ISI). The framework, whose version 2.0 was launched in 2012, includes sustainable criteria to be considered during the plan, design, construction and operation of infrastructure projects. Envision is intended to cover social, environmental and economic issues in infrastructure projects by implementing sustainable initiatives to different stages of the project lifecycle, including stakeholder involvement, preservation of historical and cultural heritage, use of renewables energies, reduction of emissions and actions to enhance resilience from a restorative perspective.

Table 3 shows the organization of Envision Version 2.0 Stage 2, which encompasses 60 credits grouped into five categories that address major issues related to the pillars of sustainability. No mandatory credits are incorporated into the framework; however, innovation points are granted to award practices which reach exceptional performance. The system sets five levels of achievement to infrastructure projects based on their degree of performance: Improved (above conventional), Enhanced (in adherence to Envision principles), Superior (noteworthy), Conserving (zero impacts) and Restorative (ability to restore natural or social systems). Bronze, Silver, Gold and Platinum awards are the four Envision certification levels according to the score achieved. 
Table 2. List of prerequisites and credits covered by LEED ND version 4 .

\begin{tabular}{|c|c|c|c|c|c|}
\hline \multicolumn{2}{|c|}{ SLL Smart Location and Linkage } & \multicolumn{2}{|c|}{ NPD Neighbourhood Pattern and Design } & \multicolumn{2}{|c|}{ GIB Green Infrastructure and Buildings } \\
\hline $\begin{array}{l}\text { Prerequisite/ } \\
\text { Credit }\end{array}$ & Concept & $\begin{array}{l}\text { Prerequisite/ } \\
\text { Credit }\end{array}$ & Concept & $\begin{array}{l}\text { Prerequisite/ } \\
\text { Credit }\end{array}$ & Concept \\
\hline SLL P1 & Smart Location & NPD P1 & Walkable Streets & GIB P1 & Certified Green Building \\
\hline SLL P2 & $\begin{array}{l}\text { Imperilled Species and Ecological } \\
\text { Community Conservation }\end{array}$ & NPD P2 & Compact Development & GIB P2 & Minimum Building Energy Performance \\
\hline SLL P3 & Wetland and Water Body Conservation & NPD P3 & Connected and Open Community & GIB P3 & Indoor Water Use Reduction \\
\hline SLL P4 & Agricultural Land Conservation & NPD C1 & Walkable Streets & GIB P4 & $\begin{array}{l}\text { Construction Activity Pollution } \\
\text { Prevention }\end{array}$ \\
\hline SLL P5 & Floodplain Avoidance & NPD C2 & Compact Development & GIB C1 & Certified Green Buildings \\
\hline SLL C1 & Preferred Locations & NPD C3 & Mixed-Use Neighbourhoods & GIB C2 & Optimize Building Energy Performance \\
\hline SLL C2 & Brownfield Remediation & NPD C4 & Housing Types and Affordability & GIB C3 & Indoor Water Use Reduction \\
\hline SLL C3 & Access to Quality Transit & NPD C5 & Reduced Parking Footprint & GIB C4 & Outdoor Water Use Reduction \\
\hline SLL C4 & Bicycle Facilities & NPD C6 & Connected and Open Community & GIB C5 & Building Reuse \\
\hline SLL C5 & Housing and Jobs Proximity & NPD C7 & Transit Facilities & GIB C6 & $\begin{array}{l}\text { Historic Resource Preservation and } \\
\text { Adaptive Reuse }\end{array}$ \\
\hline SLL C6 & Steep Slope Protection & NPD C8 & Transportation Demand Management & GIB C7 & Minimized Site Disturbance \\
\hline SLL C7 & $\begin{array}{l}\text { Site Design for Habitat or Wetland and } \\
\text { Water Body Conservation }\end{array}$ & NPD C9 & Access to Civic and Public Space & GIB C 8 & Rainwater Management \\
\hline SLL C8 & $\begin{array}{l}\text { Restoration of Habitat or Wetlands and } \\
\text { Water Bodies }\end{array}$ & NPD C10 & Access to Recreation Facilities & GIB C9 & Heat Island Reduction \\
\hline \multirow[t]{8}{*}{ SLL C9 } & $\begin{array}{l}\text { Long-Term Conservation Management } \\
\text { of Habitat or Wetlands and Water } \\
\text { Bodies }\end{array}$ & NPD C11 & Visitability and Universal Design & GIB C10 & Solar Orientation \\
\hline & & NPD C12 & Community Outreach and Involvement & GIB C11 & Renewable Energy Production \\
\hline & & NPD C13 & Local Food Production & GIB C12 & District Heating and Cooling \\
\hline & & NPD C14 & Tree-Lined and Shaded Streetscapes & GIB C13 & Infrastructure Energy Efficiency \\
\hline & & NPD C15 & Neighbourhood Schools & GIB C14 & Wastewater Management \\
\hline & & & & GIB C15 & Recycled and Reused Infrastructure \\
\hline & & & & GIB C16 & Solid Waste Management \\
\hline & & & & GIB C17 & Light Pollution Reduction \\
\hline
\end{tabular}


Table 3. List of credits specified in Envision version 2.0 stage 2.

\begin{tabular}{|c|c|c|c|c|}
\hline QL Quality of Life Credits & LD Leadership Credits & RA Resource Allocation Credits & NW Natural World Credits & CR Climate and Risk Credits \\
\hline 1 Purpose & 1 Collaboration & 1 Materials & 1 Siting & 1 Emissions \\
\hline $\begin{array}{l}\text { QL1.1 Improve Community Quality } \\
\text { of Life }\end{array}$ & $\begin{array}{l}\text { LD1.1 Provide Effective Leadership \& } \\
\text { Commitment }\end{array}$ & RA1.1 Reduce Net Embodied Energy & NW 1.1 Preserve Prime Habitat & $\begin{array}{l}\text { CR1.1 Reduce Greenhouse Gas } \\
\text { Emissions }\end{array}$ \\
\hline $\begin{array}{l}\text { QL1.2 Stimulate Sustainable Growth } \\
\& \text { Development }\end{array}$ & $\begin{array}{l}\text { LD1.2 Establish a Sustainability Management } \\
\text { System }\end{array}$ & $\begin{array}{l}\text { RA1.2 Support Sustainable Procurement } \\
\text { Practices }\end{array}$ & NW 1.2 Protect Wetlands \& Surface Water & $\begin{array}{l}\text { CR1.2 Reduce Air Pollutant } \\
\text { Emissions }\end{array}$ \\
\hline \multirow[t]{5}{*}{$\begin{array}{l}\text { QL1.3 Develop Local Skills \& } \\
\text { Capabilities }\end{array}$} & LD1.3 Foster Collaboration \& Teamwork & RA1.3 Use Recycled Materials & NW 1.3 Preserve Prime Farmland & \\
\hline & LD1.4 Provide for Stakeholder Involvement & RA1.4 Use Regional Materials & NW 1.4 Avoid Adverse Geology & \\
\hline & & RA1.5 Divert Waste from Landfills & NW1.5 Preserve Floodplain Functions & \\
\hline & & $\begin{array}{l}\text { RA1.6 Reduce Excavated Materials Taken Off } \\
\text { Site }\end{array}$ & $\begin{array}{l}\text { NW1.6 Avoid Unsuitable Development on } \\
\text { Steep Slopes }\end{array}$ & \\
\hline & & $\begin{array}{l}\text { RA1.7 Provide for Deconstruction \& } \\
\text { Recycling }\end{array}$ & NW1.7 Preserve Greenfields & \\
\hline 2 Wellbeing & 2 Management & 2 Energy & 2 Land + Water & 2 Resilience \\
\hline $\begin{array}{l}\text { QL2.1 Enhance Public Health \& } \\
\text { Safety }\end{array}$ & $\begin{array}{l}\text { LD2.1 Pursue By-Product Synergy } \\
\text { Opportunities }\end{array}$ & RA2.1 Reduce Energy Consumption & NW2.1 Manage Storm water & CR2.1 Assess Climate Threat \\
\hline QL2.2 Minimize Noise and Vibration & LD2.2 Improve Infrastructure Integration & RA2.2 Use Renewable Energy & NW2.2 Reduce Pesticide \& Fertilizer Impacts & CR2.2 Avoid Traps \& Vulnerabilities \\
\hline QL2.3 Minimize Light Pollution & & $\begin{array}{l}\text { RA2.3 Commission \& Monitor Energy } \\
\text { Systems }\end{array}$ & $\begin{array}{l}\text { NW2.3 Prevent Surface \& Groundwater } \\
\text { Contamination }\end{array}$ & $\begin{array}{l}\text { CR2.3 Prepare for Long-Term } \\
\text { Adaptability }\end{array}$ \\
\hline $\begin{array}{l}\text { QL2.4 Improve Community Mobility } \\
\& \text { Access }\end{array}$ & & & & $\begin{array}{l}\text { CR2.4 Prepare for Short-Term } \\
\text { Hazards }\end{array}$ \\
\hline $\begin{array}{l}\text { QL2.5 Encourage Alternative Modes } \\
\text { of Transportation }\end{array}$ & & & & CR2.5 Manage Heat Island Effects \\
\hline \multicolumn{5}{|l|}{$\begin{array}{l}\text { QL2.6 Improve Site Accessibility, } \\
\text { Safety \& Wayfinding }\end{array}$} \\
\hline 3 Community & 3 Planning & 3 Water & 3 Biodiversity & \\
\hline $\begin{array}{l}\text { QL3.1 Preserve Historic \& Cultural } \\
\text { Resources }\end{array}$ & $\begin{array}{l}\text { LD3.1 Plan for Long-Term Monitoring \& } \\
\text { Maintenance }\end{array}$ & RA3.1 Protect Fresh Water Availability & NW3.1 Preserve Species Biodiversity & \\
\hline $\begin{array}{l}\text { QL3.2 Preserve Views \& Local } \\
\text { Character }\end{array}$ & $\begin{array}{l}\text { LD3.2 Address Conflicting Regulations \& } \\
\text { Policies }\end{array}$ & RA3.2 Reduce Potable Water Consumption & NW3.2 Control Invasive Species & \\
\hline \multirow[t]{2}{*}{ QL3.3 Enhance Public Space } & LD3.3 Extend Useful Life & RA3.3 Monitor Water Systems & NW3.3 Restore Disturbed Soils & \\
\hline & & & $\begin{array}{l}\text { NW3.4 Maintain Wetland \& Surface Water } \\
\text { Functions }\end{array}$ & \\
\hline $\begin{array}{l}\text { QL0.0 Innovate or Exceed Credit } \\
\text { Requirements }\end{array}$ & $\begin{array}{l}\text { LD0.0 Innovate or Exceed Credit } \\
\text { Requirements }\end{array}$ & $\begin{array}{l}\text { RA0.0 Innovate or Exceed Credit } \\
\text { Requirements }\end{array}$ & $\begin{array}{l}\text { NW0.0 Innovate or Exceed Credit } \\
\text { Requirements }\end{array}$ & $\begin{array}{l}\text { CR0.0 Innovate or Exceed Credit } \\
\text { Requirements }\end{array}$ \\
\hline
\end{tabular}




\section{Assessment of LEED ND and Envision in Terms of Sustainable Development}

As a consequence of the prominent efforts led by the international community through the implementation and achievement of the SDGs to promote sustainable development worldwide, this framework and the New Urban Agenda were considered as a benchmark to appraise LEED ND and Envision. To lay the foundations required to conduct such an assessment, the liaison between the New Urban Agenda adopted to address sustainable urban development and the SDGs was firstly established as a preliminary step. Although the Agenda consists of 175 items lacking specific metrics for their monitoring, only those (110) related to call for actions and implementation plan were assessed, distributing them into social, economic, environmental and managerial categories as well. The remaining 65 points were not relevant for the research because they are part of minor sections such as preamble, shared vision, principles and commitments, means of implementation or follow-up and review. Similarly, the SDGs were allocated to the pillars of sustainability. Next, the credits and prerequisites of LEED ND and Envision were sorted according to the correlation to the sustainable dimensions and the SDGs. Finally, the section ends with a discussion of the main findings stemming from the assessment.

\subsection{Effects of Unplanned Urbanization in Developing Countries}

The movement of population from rural to urban areas during the last decades is sharpening unplanned urbanization, which provides social and economic enhancements, but also concerns such as inequalities, poor infrastructure, lack of basic services and spread of diseases. Potential risks that threaten society might be addressed by efficient governance of cities, planning urban settlements to facilitate socio-economic development and facing inefficient management of resources, effects of climate change and pollution. The process of urbanization is being accelerated as a consequence of rural-urban migration, whereby people aim to find best job opportunities and better life conditions in cities.

The quality of infrastructure has a great impact on standard of living, social inclusion, economic opportunities of inhabitants and the resilience of cities to several environmental, social and health-related risks. The availability and adequacy of infrastructure represents a challenge for urban settlements in poorer countries, where the lack of investment in maintenance impacts on infrastructure, electric power and water supply, sanitation and communications. Moreover, infrastructure failure might adversely affect property and business continuity.

A better access to education, healthcare and living conditions as part of urbanization process could contribute to enhance welfare of urban population. However, unplanned urbanization can bring the opposite effect by fostering high population density, spreading diseases, rising poverty and lacking proper infrastructure. Inadequate sanitation is suffered by almost 700 million individuals nowadays, mostly in sub-Saharan Africa and south-central Asia, where slums proliferate causing high levels of exposure to illnesses, such as typhus, cholera and diarrhoea [38]. Flooding vulnerability is another effect of unplanned settlements located near the riverbank or the sea. Coastal zones host more than half of megacities in the world, which are threatened by the rise of sea-level. Urban resilience has become a priority to face extreme weather events for public and private sectors.

Rural population leaving the countryside towards urban areas in the search for economic prosperity often encounter serious difficulties, such as the lack of decent housing or the high cost of living, which can lead individuals to deprivation and social exclusion. Hence, the potential emergence of violence and social unrest outbreaks can turn into impunity and weak city governance. Increasing gaps in incomes and social inequalities bind the circle of the process to engage uncontrolled immigration to cities. 


\subsection{Correlation between Sustainable Development Goals and the New Urban Agenda}

The New Urban Agenda includes a holistic view of urban settlements through the fulfilment of their social function, achieving the full realization of the right to adequate housing without discrimination, as well as universal access to safe and affordable drinking water and sanitation. Furthermore, participation of inhabitants enables social and intergenerational interactions and cultural expressions, fostering social cohesion. Gender equality, empowerment of women and involvement of people also contribute to reducing discrimination. Leveraging urbanization for structural transformation, efficient and accessible transport systems for passengers and freight, high productivity, value-added activities and resource efficiency boost local economies, whilst mitigation and resilience to climate change are managed through the implementation of disaster risk practices. Protection, conservation and restoration of ecosystems, water, natural habitats and biodiversity should be promoted by cities which are able to adopt sustainable consumption and production patterns.

In the absence of tangible indicators in the Agenda, Table 4 shows the correlation between all 110 calls for action and implementation plan points included in the document, from item \#16 to \#125, and the 17 SDGs. SDG \#11 ("Sustainable Cities and Communities") includes 46 of these items, which assert the main commitment from the international urban agreement, whilst SDG \#17 ("Partnerships for the Goals") considers 27 different actions aimed at searching for collaboration between governments, private sector and society.

Figure 2 illustrates the distribution of SDGs and the Agenda items among the social, economic, environmental and managerial dimensions of sustainability. Regarding the SDGs, the social and environmental aspects are the most relevant $(29.41 \%)$, whilst the managerial and economic pillars are less important $(23.53 \%$ and $17.65 \%$, respectively). In contrast, the managerial dimension encompasses the highest amount of the New Urban Agenda items (73.64\%), followed by the social and economic considerations $(9.09 \%$ each) and the environmental concerns $(8.18 \%)$.

Table 4. Correlation between the New Urban Agenda items and the Sustainable Development Goals (SDGs).

\begin{tabular}{|c|c|c|}
\hline SDG \# & Concept & New Urban Agenda Item \# \\
\hline 1 & No Poverty & 25 \\
\hline 2 & Zero Hunger & 123 \\
\hline 3 & Good Health and Well-being & 95 \\
\hline 4 & Quality Education & 61 \\
\hline 5 & Gender Equality & - \\
\hline 6 & Clean Water and Sanitation & 73,120 \\
\hline 7 & Affordable and Clean Energy & $54,75,121$ \\
\hline 8 & Decent Work and Economic Growth & $43,44,56,57,58,59,60$ \\
\hline 9 & Industry, Innovation and Infrastructure & 45 \\
\hline 10 & Reduced Inequalities & $20,27,28,33,36,40,62,89$ \\
\hline 11 & Sustainable Cities and Communities & $\begin{array}{c}30,34,37,46,49,50,51,52,53,55,63,66,67,72,77,78,80,87 \\
88,90,91,92,94,96,97,98,99,100,101,102,103,107,108 \\
109,110,111,112,113,114,115,116,117,118,119,124,125\end{array}$ \\
\hline 12 & Responsible Consumption and Production & $65,70,71,74,76,122$ \\
\hline 13 & Climate Action & 64,79 \\
\hline 14 & Life Below Water & - \\
\hline 15 & Life on Land & 68,69 \\
\hline 16 & Peace, Justice and Strong Institutions & 39,41 \\
\hline 17 & Partnerships for The Goals & $\begin{array}{c}16,17,18,19,21,22,23,24,26,29,31,32,35,38,42,47,48 \\
81,82,83,84,85,86,93,104,105,106\end{array}$ \\
\hline
\end{tabular}




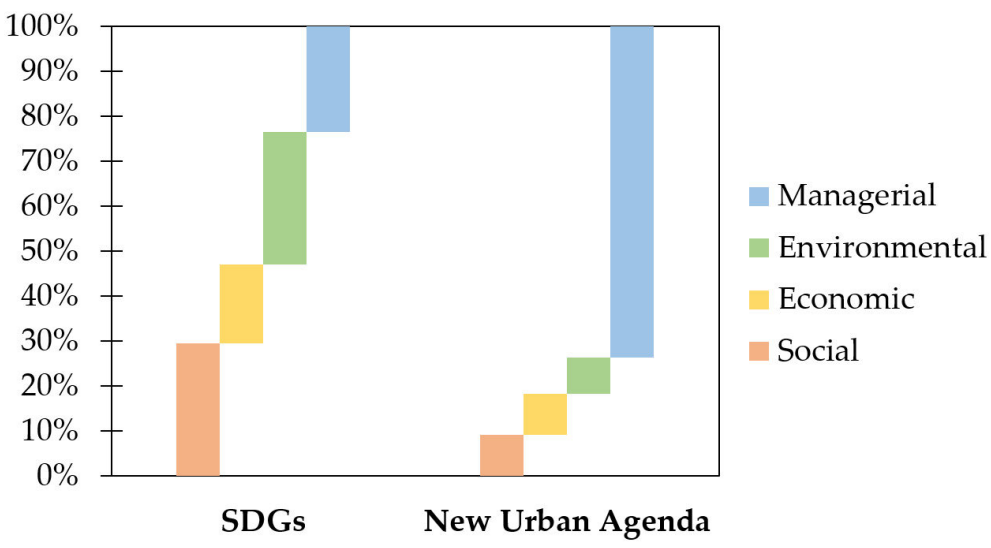

Figure 2. Distribution of Sustainable Development Goals (SDGs) and the New Urban Agenda items across the sustainable dimensions.

\subsection{Assessment of LEED ND and Envision for Their Application in Developing Countries According to the} SDGs and the New Urban Agenda

The SDGs and the New Urban Agenda are both the most recent frameworks adopted by the United Nations in the field of sustainable development to lead the way for the next decades. World population is experiencing a fast-growing that will impact human settlements significantly, which is the reason why the contribution of international agreements will be crucial to strengthen sustainable urban development worldwide, particularly in developing countries where the concentration of people will be higher.

LEED ND and Envision were the two sustainable rating systems selected to determine their suitability to be applied for assessing urban development in poorer countries, according to the SDGs and the Agenda. Most of prerequisites and credits from LEED ND and Envision are concentrated on environmental and managerial dimensions, as shown in Figure 3. The remaining credits considered in Envision are equally distributed between the social and economic aspects, whereas LEED ND includes no element in the economic area.

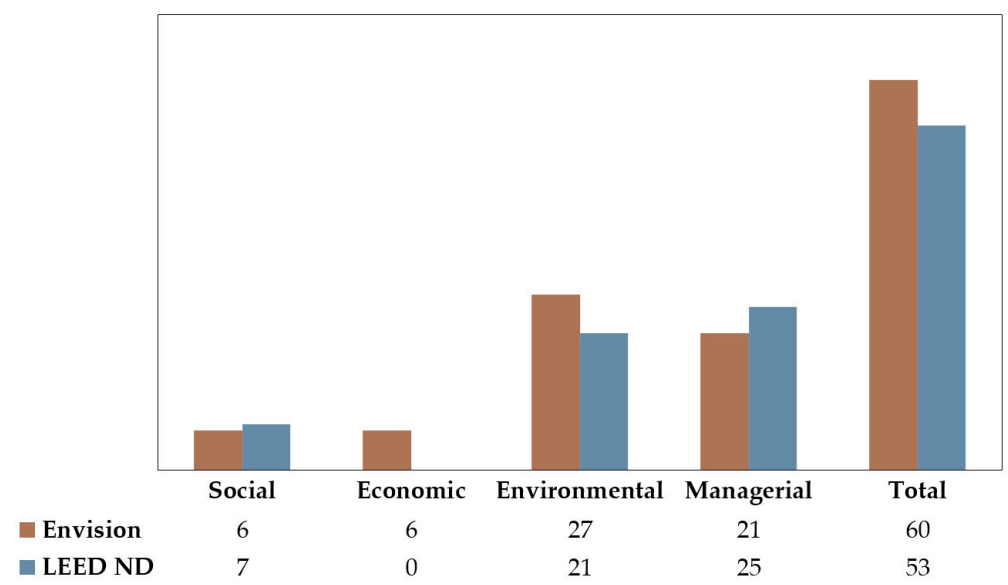

Figure 3. Distribution of Envision credits and LEED ND prerequisites and credits across sustainable dimensions.

Due to the lack of quantitative parameters in the New Urban Agenda, all its items were linked to the SDGs to set a valid benchmark for assessing Envision and LEED ND. Table 5 includes the relationship between the elements included in the SDGs and the Agenda, as well as the prerequisites and credits of LEED ND and Envision. 
Table 5. Interrelation among SDGs, New Urban Agenda items, Envision credits and LEED ND prerequisites and credits.

\begin{tabular}{|c|c|c|c|c|}
\hline SDG \# & Concept & New Urban Agenda Item \# & Envision Credits & $\begin{array}{l}\text { LEED ND Prerequisites and } \\
\text { Credits }\end{array}$ \\
\hline 1 & No Poverty & 25 & - & - \\
\hline 2 & Zero Hunger & 123 & - & - \\
\hline 3 & $\begin{array}{l}\text { Good Health and } \\
\text { Well-being }\end{array}$ & 95 & $\begin{array}{l}\text { QL 1.1, QL 2.1, QL 2.2, QL 2.3, } \\
\text { CR 1.2, QL } 0.0\end{array}$ & $\begin{array}{l}\text { SLL C4, NPD C8, NPD C9, } \\
\text { NPD C10, NPD C13, GIB P4, } \\
\text { GIB C17 }\end{array}$ \\
\hline 4 & Quality Education & 61 & - & - \\
\hline 5 & Gender Equality & - & - & - \\
\hline 6 & $\begin{array}{l}\text { Clean Water and } \\
\text { Sanitation }\end{array}$ & 73,120 & RA 3.2, RA 3.3, & GIB P3, GIB C3, GIB C4, GIB C14 \\
\hline 7 & $\begin{array}{l}\text { Affordable and } \\
\text { Clean Energy }\end{array}$ & $54,75,121$ & RA 2.1, RA 2.2, RA 2.3, & $\begin{array}{l}\text { GIB P2, GIB C2, GIB C10, GIB C11, } \\
\text { GIB C12, GIB C13, }\end{array}$ \\
\hline 8 & $\begin{array}{l}\text { Decent Work and } \\
\text { Economic Growth }\end{array}$ & $43,44,56,57,58,59,60$ & QL 1.2, QL 1.3 & - \\
\hline 9 & $\begin{array}{l}\text { Industry, } \\
\text { Innovation and } \\
\text { Infrastructure }\end{array}$ & 45 & QL 2.4, QL 2.5, QL 2.6, LD 2.2 & - \\
\hline 10 & $\begin{array}{c}\text { Reduced } \\
\text { Inequalities }\end{array}$ & $20,27,28,33,36,40,62,89$ & - & - \\
\hline 11 & $\begin{array}{l}\text { Sustainable Cities } \\
\text { and Communities }\end{array}$ & $\begin{array}{c}30,34,37,46,49,50,51,52,53 \\
55,63,66,67,72,77,78,80,87 \\
88,90,91,92,94,96,97,98,99 \\
100,101,102,103,107,108,109 \\
110,111,112,113,114,115,116 \\
117,118,119,124,125\end{array}$ & $\begin{array}{c}\text { QL 3.1, QL 3.2, QL 3.3, LD3.1, } \\
\text { LD } 3.3\end{array}$ & $\begin{array}{l}\text { SLL P1, SLL C1, SLL C2, SLL C3, } \\
\text { SLL C5, NPD P1, NPD P2, NPD P3, } \\
\text { NPD C1, NPD C2, NPD C3, } \\
\text { NPD C4, NPD C5, NPD C6, } \\
\text { NPD C7, NPD C11, NPD C14, } \\
\text { NPD C15, GIB P1, GIB C1 }\end{array}$ \\
\hline 12 & $\begin{array}{l}\text { Responsible } \\
\text { Consumption and } \\
\text { Production }\end{array}$ & $65,70,71,74,76,122$ & $\begin{array}{c}\text { LD 2.1, RA 1.1, RA 1.2, RA 1.3, } \\
\text { RA 1.4, RA 1.5, RA 1.7, RA 3.1, } \\
\text { NW 2.2, RA } 0.0\end{array}$ & GIB C5, GIB C6, GIB C15, GIB C16 \\
\hline 13 & Climate Action & 64,79 & $\begin{array}{l}\text { CR 1.1, CR 2.1, CR 2.2, CR 2.3, } \\
\text { CR 2.4, CR 2.5, CR } 0.0\end{array}$ & GIB C9 \\
\hline 14 & Life Below Water & - & - & - \\
\hline 15 & Life on Land & 68,69 & $\begin{array}{l}\text { RA 1.6, NW 1.1, NW 1.2, } \\
\text { NW 1.3, NW 1.4, NW 1.5, } \\
\text { NW 1.6, NW 1.7, NW 2.1, } \\
\text { NW 2.3, NW 3.1, NW 3.2, } \\
\text { NW 3.3, NW 3.4, NW } 0.0\end{array}$ & $\begin{array}{l}\text { SLL P2, SLL P3, SLL P4, SLL P5, } \\
\text { SLL C6, SLL C7, SLL C8, SLL C9, } \\
\text { GIB C7, GIB C8 }\end{array}$ \\
\hline 16 & $\begin{array}{l}\text { Peace, Justice and } \\
\text { Strong Institutions }\end{array}$ & 39,41 & LD 1.3, LD 1.4 & NPD C12 \\
\hline 17 & $\begin{array}{l}\text { Partnerships for } \\
\text { The Goals }\end{array}$ & $\begin{array}{c}16,17,18,19,21,22,23,24,26 \\
29,31,32,35,38,42,47,48,81 \\
82,83,84,85,86,93,104,105,106\end{array}$ & LD 1.1, LD 1.2, LD 3.2, LD 0.0 & - \\
\hline
\end{tabular}

Social issues targeted in some SDGs, such as \#1 ("Poverty"), \#2 ("Zero Hunger"), \#4 ("Quality Education"), \#5 (“Gender Equality"), \#10 ("Reduced inequalities"), \#14 ("Life below Water"), were not considered by Envision nor by LEED ND. Furthermore, the latter did not cover some other SDGs at all either, such as \#8 ("Decent Work and Economic Growth"), \#9 ("Industry, Innovation and Infrastructure") and \#17 ("Partnership for the Goals"). Therefore, Envision includes more SDGs in its framework (11) than LEED ND (only 8). However, LEED ND clearly outperforms Envision in terms of urban development, since it considers 20 prerequisites and credits related to the targets in SDG \#11 ("Sustainable Cities and Communities").

Figure 4 depicts the allocation of Envision credits, LEED ND prerequisites and credits and the New Urban Agenda items among the SDGs. SDGs \#15 ("Life on Land") and \#12 ("Responsible Consumption and Production") involve the largest number of Envision credits with 15 and 10, respectively. In contrast, SDGs \#6 ("Clean Water and Sanitation"), \#8 ("Decent Work and Economic Growth") and \#16 ("Peace"), Justice and Strong Institutions only includes 2 credits. Regarding LEED ND, whilst SDG \#11 Sustainable Cities and Communities involves the highest number of prerequisites and credits, SDG \#13 Climate Action and \#16 Peace, Justice and Strong Institutions only have 1. 


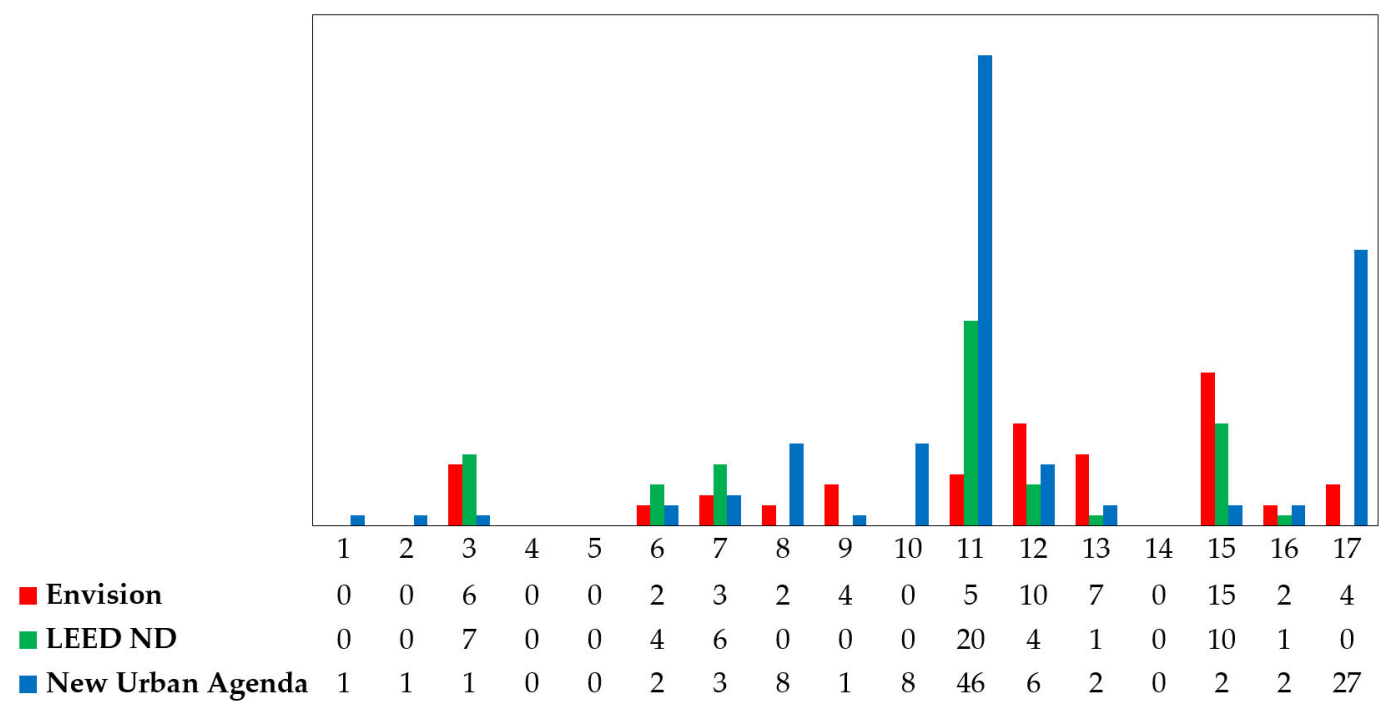

Figure 4. Distribution of Envision credits, LEED ND prerequisites and credits and New Urban Agenda items across the Sustainable Development Goals (SDGs).

\subsection{Discussion}

Although the New Urban Agenda encloses 175 points, among which only 110 of them are directly connected to clear actions targeted at promoting sustainable urban development, the total absence of metrics made their accurate allocation to the SDGs highly complicated, in spite of its explicit commitment towards the achievement of the latter. More than $66 \%$ of its items are focused on the SDGs \#11 ("Sustainable Cities and Communities") and 17 ("Partnerships for the Goals"), which cover two rather general objectives that hinder the concretization of specific measures to address sustainable urban issues. In contrast, some prominent topics which harshly impact on urban settlements, represented by the SDGs \#1 ("No Poverty"), 2 ("Zero Hunger"), 3 ("Good Health and Wellbeing"), 4 ("Quality Education"), 5 ("Gender Equality") or 6 ("Clean Water and Sanitation"), were only supported by 1 action each. Although strong institutions should become sound foundations for the sustainable development of cities to avoid that social and economic inequalities evolve to marginalization and violence, the SDG \#16 ("Peace, Justice and Strong Institutions") just collected 2 actions from the Agenda.

The consideration of the sustainable dimensions by the SDGs and the New Urban Agenda varies significantly. Whilst the former is in line with distributing the sustainable goals among the 4 dimensions equally, the latter concentrates most of its actions on the managerial aspect, leaving the other pillars as residuals. Thus, the New Urban Agenda is unsuitable to enhance specific urban concerns related to the sustainable dimensions.

The distribution of prerequisites and credits of LEED ND and Envision confirmed their approach towards environmental and managerial aspects in detriment of the social and economic dimensions. LEED ND metrics even skip the latter because of its lack of attention to the economic growth associated with building projects. The fact that both frameworks were developed and launched in the United States to deal mainly with tangible issues such as efficient resource management, pollution and climate change effects determined this bias. The Envision category called "Quality of Life", primarily focused on individuals, allocated some credits to social and economic dimensions.

The disregard of most social-oriented SDGs by Envision and LEED ND, namely \#2 ("Zero Hunger"), \#4 (“Quality Education"), \#5 ("Gender Equality") and \#10 ("Reduced inequalities"), reaffirmed that these frameworks are founded on national concerns associated with their country of origin and omit global challenges. However, both systems devoted several credits to enhance SDG \#3 ("Good Health and Well-Being"). Envision showed the greatest concerns related to managerial 
and environmental aspects by assigning the largest number of credits to the SDGs \#12 ("Responsible Consumption and Production") and \#15 ("Life on Land"), which are usually associated with developed countries. In accordance with its scope, LEED ND allocated the largest amount of credits to the SDGs \#11 ("Sustainable Cities and Communities") and 15 ("Life on Land"), setting aside other SDGs correlated to poorer countries, such as \#8 ("Decent Work and Economic Growth"), \#9 ("Industry, Innovation and Infrastructure"), \#16 ("Peace, Justice and Strong Institutions") and \#17 ("Partnerships for the Goals").

\section{Conclusions}

This article analysed the suitability of the LEED for Neighbourhood Development and Envision rating systems for their application to appraise urban development in poorer countries from the perspective of the Sustainable Development Goals (SDGs) and the New Urban Agenda adopted by the United Nations. The specific conclusions derived from this research are given below:

- The absence of metrics in the New Urban Agenda makes its effective implementation worldwide highly difficult. Thus, its explicit commitment to support the achievement of the SDGs remains imprecise and limited.

- Whilst the SDGs reached a balance among social, environmental, economic and managerial dimensions in comparison with its predecessors, the Millennium Development Goals (MDGs), the New Urban Agenda concentrates most of its actions on the managerial aspect, which is much more intangible than the pillars of the Triple Bottom Line.

- LEED ND and Envision allocated most of their credits and prerequisites to a limited number of SDGs, mainly oriented to national issues related to their country of origin. However, outstanding challenges with an effect on large part of the world population are fully ignored. In the same vein, both frameworks reflected their preference towards the environmental and managerial dimensions, in detriment of social and economic considerations.

- Although the SDG \#11 ("Sustainable Cities and Communities") includes diverse targets and indicators leading to enhance the sustainability of urban settlements, the broad concept of sustainable development is intimately associated with many other SDGs. Therefore, the accurate assessment of urban sustainability requires a further breakdown involving other SDGs related to different social and economic challenges.

Urban areas as the result of the linkage between buildings and infrastructure systems allow individuals to develop their activities, which involve social, economic and environmental aspects under strong governance foundations. Moreover, developing countries suffer from specific issues predominantly related to the social and economic dimensions, which are further exacerbated by the effect of overpopulation in towns and cities. Consequently, the four dimensions should be equally covered by a framework aimed at assessing urban sustainability in these geographical areas. Although LEED ND and Envision do not address most of the SDGs set by the UN, showing a significant bias towards the environmental and managerial aspects in detriment of economic and social matters, they are a valid starting point for the development of a new and ad-hoc framework for poorer countries.

Author Contributions: Jose Manuel Diaz-Sarachaga conceived the research; Jose Manuel Diaz-Sarachaga conducted the evaluation of sustainable rating systems; Daniel Castro-Fresno supervised the development of the investigation; Jose Manuel Diaz-Sarachaga and Daniel Jato-Espino discussed the results; and Jose Manuel Diaz-Sarachaga and Daniel Jato-Espino wrote the paper.

Conflicts of Interest: The authors declare no conflict of interest. The founding sponsors had no role in the design of the study; in the collection, analyses, or interpretation of data; in the writing of the manuscript, and in the decision to publish the results. 


\section{References}

1. European Commission (EC). Communication from the Commission: A Sustainable Europe for a better World: A European Union Strategy for Sustainable Development; European Commission: Brussels, Belgium, 2001.

2. United Nations Department of Economic and Social Affairs (UN-DESA). World Population Prospects. Key Findings and Advance Tables; United Nations Department of Economic and Social Affairs: New York, NY, USA, 2015.

3. Transforming Our World: The 2030 Agenda for Sustainable Development. Available online: https:// sustainabledevelopment.un.org/post2015/transformingourworld (accessed on 2 January 2017).

4. United Nations Department of Economic and Social Affairs (UN-DESA). World Urbanization Prospects; United Nations Department of Economic and Social Affairs: New York, NY, USA, 2014.

5. Science for Environment Policy. In-Depth Reports. Available online: http:/ /ec.europa.eu/environment/ integration/research/newsalert/indepth_reports.htm (accessed on 4 March 2017).

6. U.S. Green Building Council (USGBC). LEED Reference Guide for Neighbourhood Development V4; U.S. Green Building Council: Washington, NY, USA, 2014.

7. Institute for Sustainable Infrastructure. Available online: https://Sustainableinfrastructure.org/ (accessed on 12 January 2017).

8. Report of United Nations Conference on Environment and Development. Available online: http://www.un. org/documents/ga/conf151/aconf15126-1annex1.htm (accessed on 1 February 2017).

9. United Nations Economic Commission for Europe (UNECE). The CSD Work Programme on Indicators of Sustainable Development; United Nations Economic Commission for Europe: New York, NY, USA, 2001.

10. Commission on Sustainable Development (CSD). Available online: https://sustainabledevelopment.un.org/ intergovernmental/csd (accessed on 18 December 2016).

11. World Summit on Sustainable Development (WSSD). Johannesburg Summit. Available online: https: / / sustainabledevelopment.un.org/milesstones/wssd (accessed on 3 January 2017).

12. United Nations Department of Economic and Social Affairs (UN-DESA). Indicators of Sustainable Development: Guidelines and Methodologies; United Nations Department of Economic and Social Affairs: New York, NY, USA, 2007.

13. United Nations Commission on Sustainable Development (UNCSD). Agenda 21: Earth Summit-The United Nations Programme of Action from Rio; United Nations Commission on Sustainable Development: New York, NY, USA, 1993.

14. Resolution 55/2. United Nations Millennium Declaration. Available online: http://www.un.org/ millennium/declaration/ares552e.htm (accessed on 2 February 2017).

15. Indicators and a Monitoring Framework for the Sustainable Development Goals. Available online: https: / / sustainabledevelopment.un.org/index.php?page=view\&type=400\&nr=2013\&menu=35 (accessed on 6 February 2017).

16. The Vancouver Declaration on Human Settlements. Available online: http://habitat.igc.org/vancouver/ van-decl.htm (accessed on 14 February 2017).

17. United Nations Human Settlements Programme (UN-Habitat). Report of the UN Conference on Human Settlements (Habitat II); United Nations Human Settlements Programme: Istanbul, Turkey, 1996.

18. The New Urban Agenda. Available online: http:/ / habitat3.org/the-new-urban-agenda (accessed on 15 February 2017).

19. United Nations Conference on Sustainable Development, Rio+20. Available online: https:// sustainabledevelopment.un.org/rio20 (accessed on 4 March 2017).

20. Yigitcalar, T.; Lönnqvist, A. Benchmarking knowledge-based urban development performance: Results from the International comparison of Helsinki. Cities 2013, 31, 357-369. [CrossRef]

21. Shen, L.Y.; Ochoa, J.; Shah, M.N.; Zhang, X. The application of urban sustainability indicators-A comparison between various practices. Habitat Int. 2011, 35, 17-29. [CrossRef]

22. Moreno Pires, S.; Fidélis, T.; Ramos, T.B. Measuring and comparing local sustainable development through common indicators: Constraints and achievements in practice. Cities 2014, 39, 1-9. [CrossRef]

23. European Environmental Agency (EEA). Developing a Pragmatic Approach to Assess Urban Metabolism in Europe; European Environmental Agency: Berlin, Germany, 2010. 
24. European Green Capital. Available online: http://ec.europa.eu/environment/europeangreencapital/index_ en.htm (accessed on 23 January 2017).

25. Siemens AG. The Green City Index. A Summary of the Green City Index Research Series; Corporate Communications and Government Affairs: München, Germany, 2012.

26. The Reference Framework for Sustainable Cities. Available online: http://rfsc.eu/ (accessed on 23 December 2016).

27. Berrini, M.; Bono, L. Report 2007 Urban Ecosystem Europe. An Integrated Assessment on the Sustainability of 32 European Cities; Ambiente Italia Research Institute: Milan, Italy, 2007.

28. Mega, V.; Pedersen, J. Urban Sustainability Indicators; European Foundation for the Improvement of Living and Working Conditions: Dublin, Ireland, 1998; ISBN 92-828-4669-5.

29. The Global City Indicators Program: A More Credible Voice for Cities. Available online: https:// openknowledge.worldbank.org/handle/10986/10244 (accessed on 8 December 2016).

30. Sustainable Cities International (SCI). Indicators for Sustainability. How Cities Are Monitoring and Evaluating Their Success; Sustainable Cities International: Vancouver, BC, Canada, 2012.

31. BREEAM Communities. Technical Manual, BRE Global Ltd.: Glasgow, UK, 2009.

32. Outline of Casbee for Urban Development (CASBEE for UD). Technical Manual; Institute for Building Environment and Energy Conservation: Tokyo, Japan, 2007.

33. STAR Communities. Available online: http://www.starcommunities.org/ (accessed on 14 December 2016).

34. Eco2 Cities. Ecological Cities as Economical Cities. Available online: http://web.worldbank.org/WBSITE/ EXTERNAL/TOPICS/EXTURBANDEVELOPMENT/0,, contentMDK:22501973 pagePK:148956 piPK: 216618 theSitePK:337178,00.html (accessed on 9 March 2017).

35. Green Star Rating System. Available online: http://new.gbca.org.au/green-star/rating-system/ (accessed on 14 February 2017).

36. Infrastructure Sustainability Council of Australia. IS Overview. Available online: https://isca.org.au/israting-scheme/about-is (accessed on 28 January 2017).

37. CEEQUAL. Available online: http:/ / www.ceequal.com/ (accessed on 17 February 2017).

38. World Economic Forum. Global Risks 2015, 10th ed.; World Economic Forum: Geneva, Switzerland, 2015. 